\title{
Chemical and Biological Studies of Cyanobacteria
}

\section{Mohammad Shoeb}

\author{
Department of Chemistry, University of Dhaka, Dhaka-1000, Bangladesh
}

Received: April 08, 2014; Accepted: June 10, 2014; Published (web): July 06, 2014

\begin{abstract}
Cyanobacteria are photosynthetic prokaryotic microalgae which are found in marine, brackish and freshwater environments and in soils. Cyanotoxins including hepatotoxins and neurotoxins are produced by cyanobacteria commonly found in surface water. The most widely studied hepatotoxins are microcystins and nodularin which were first isolated from Microcystis aeruginosa and Nodularia spumigena, respectively. M. aeruginosa and $N$. spumigena were cultured and extracted with methanol. The qualitative and quantitative analysis of microcystins and nodularin in cultured cyanobacterial fractions were performed by HPLC. Fluorescein diacetate (FDA) antimicrobial and brine shrimp lethality assay were carried out to determine minimum inhibitory concentration (MIC) and general toxicity of these fractions, respectively. An unusual metabolite named as nodularinol was isolated for the first time from $N$. spumigena.
\end{abstract}

Key words: Cyanobacteria, Microcystis aeruginosa, Nodularia spumigena, fluorescein diacetate, brine shrimp lethality assay

\section{INTRODUCTION}

Cyanobacteria are the scientific name for bluegreen algae, or "pond scum". The first recognized species were blue-green in colour, which is how the algae got their name. Cyanobacteria are photosynthetic prokaryotic microalgae which can exist in a wide range of environments such as arctic, hot and cold deserts, in hypersaline lakes and thermal springs. ${ }^{1-5}$ They are also found in marine, brackish and freshwater environments and in soils. The growth of cyanobacteria and formation of blooms are influenced by a variety of physical, chemical and biological factors such as temperature, light intensity, turbidity, nutrient and $\mathrm{pH}$. Fresh cyanobacteria may accumulate in surface water supplies as a "bloom" and may concentrate on the surface as a blue-green "scum". Cyanobacteria produces a wide variety of secondary metabolites. Out of the 208 compounds, about $40 \%$ of cyanobacterial compounds had anticancer activity. ${ }^{6}$ They also produce antiviral, antibacterial and antifungal compounds and toxins.

Correspondence to: Mohammad Shoeb

Cell: 01715191988;

E-mail: shoeb71@yahoo.com

Dhaka Univ. J. Pharm. Sci. 13(2): 119-124, 2014 (December)
Cyanobacterial toxins include hepatotoxins and neurotoxins which are produced by those commonly found in surface water. The most widely studied hepatotoxins are the cyclic heptapeptide microcystins, first isolated from the fresh water species M. aeruginosa. ${ }^{7,8}$ About 70 different microcystins were isolated from the planktonic cyanobacteria of Anabaena, Microcystis, Oscillatoria, Nostoc and Anabaenopsis. ${ }^{9}$ Another group of hepatotoxins called nodularins were obtained from the brackish water-dwelling cyanobacterium $N$. spumigena. And poisonings caused by them were reported since $1878 .{ }^{10}$ The fluorescein diacetate (FDA) antimicrobial assay relies on the cleavage of fluorescein diacetate by metabolically active bacteria to fluorescein, a yellowish green compound, which absorbs at the visible region. ${ }^{11}$ The assay is used to determine minimum inhibitory concentration (MIC) of antibiotics and toxins for Pseudomonas aeruginosa, Escherichia coli and Staphylococcus aureus and gives reproducible quantitative results. ${ }^{12}$ The brine shrimp lethality assay is a simple, rapid and inexpensive bioassay for determining general toxicity of samples. Usually, the eggs of Artemia salina 
Leach is used in brine solution. ${ }^{13}$ Here, the isolation of an unusual metabolite named as nodularinol from Nodularia sp. and FDA antimicrobial and brine shrimp lethality assay to determine MIC and toxicity of cyanobacterial extractives are reported.

\section{MATERIALS AND METHODS}

General. IR, mass and ${ }^{1} \mathrm{H} \&{ }^{13} \mathrm{C}$ NMR spectra data were recorded on Mattson Ati Genesis FT-IR, JEOL Mass and a Varian Unity Inova $400 \mathrm{MHz}$ NMR spectrometer, respectively.

Growth culture and extraction of cyanobacteria. $M$. aeruginosa PCC7820, $N$. spuminega PCC7804 were supplied by the Pasteur Culture Collection, Paris, France. M. aeruginosa Sciento was purchased from Sciento Education Service, Manchester, UK. Cyanobacteria were grown in BG11 medium $^{14}$ plus nitrate $\left(8.8 \mathrm{mM} \mathrm{NaNO}_{3}\right)$ under continuous illumination $\left(20 \mu \mathrm{mol} \mathrm{m} \mathrm{m}^{-2} \mathrm{~s}^{-1}\right)$ by cool white fluorescent tubes ( $36 \mathrm{~W}$ ) at the School of Life Sciences, the Robert Gordon University, UK. Flasks of eight litre volume were sparged with sterile air throughout and growth temperature was maintained $21-27^{\circ} \mathrm{C}$. Cells were harvested after approximately 5 weeks of growth by tangential flow filtration (Pellicon-2; fitted with three $0.22 \mu \mathrm{M}$, type GVPP-V filters, Millipore) and then centrifuged to give a wet pellet which was stored at $-20^{\circ} \mathrm{C}$ until required.

Separation of cyanobacterial toxins. Supernatant (40 Litres) of M. aeruginosa PCC7820 (or $M$. aeruginosa Sciento/N. spumigena) were applied to a reversed phase flash chromatography system fitted with a C-18HS column $(7.5 \times 4.0 \mathrm{~cm}$, i.d. $35-70 \mu \mathrm{m}$ particle size, 60 ' pore size). A step gradient of 25 to $100 \%$ aqueous methanol in $25 \%$ increments (500 $\mathrm{mL}$ per step) was used to elute different toxins from the column and five fractions were collected.

HPLC analysis of cyanobacterial fractions. The qualitative and quantitative analysis of microcystin and nodularin were performed by high performances liquid chromatography (HPLC). HPLC system consisted of a Waters 600E multisolvent delivery system coupled with a Waters 717 plus autosampler, and a waters 996 photodiode array, scanning 200 and 300 (Waters Corp., Milford, MA, USA). A reversed phase Waters Symmetry C18 column ( 250 x $4.6 \mathrm{~mm}$ 1.d., $5 \mu \mathrm{m}$ particle size) was used for separation of toxins. A gradient system of Milli-Q-Water and acetonitrile (acetonitrile from $30 \%$ to $70 \%$ over $40 \mathrm{~min}$, followed by $100 \%$ over 5 minutes) with $0.005 \%$ trifluroacetic acid was used as mobile phase. The flow rate of mobile phase was 1 $\mathrm{mL} / \mathrm{min}$ and the injection volume was $25 \mu \mathrm{L}$.

Fluorescein diacetate (FDA) assay of cyanobacterial franctions. Fluorescein diacetate (FDA), streptomycin, glucose, yeast extract, chloramphenicol and penicillin $\mathrm{G}$ were purchased from the Sigma Chemical Company, USA. Tryptone and glucose were purchased from Fisher Scientific UK Limited, Bishop Meadow Road, Loughborough, Leics, UK. In order to carry out the FDA assay three microorganisms and six antibiotics were screened for their efficacy on the assay.

Pseudomonas aeruginosa, Escherichia coli and Staphylococcus aureus were used to hydrolyse colorless flourescein diacetate (FDA) to fluorescein, a yellowish green compound. $P$. aeruginosa completely hydrolyzed FDA to fluorescein, producing a yellowish green colour. There were no significant colour and absorbance changes using $E$. coli and Stap. aureus which suggested that they might not be able to hydrolyse fluorescein diacetate (FDA) to fluorescein. Therefore, P. aeruginosa was selected for the assay. Six antibiotics were tested for their effectiveness against $P$. aeruginosa by the disc diffusion assay. ${ }^{15}$ It was found that streptomycin is significantly active against $P$. aeruginosa. Chloramphenicol and tetracycline were moderately active. Ampicilin, penicillin and erythromycin were inactive. Streptomycin was used as standard drug for the FDA assay.

Determination of MIC of cyanobacterial fractions by FDA assay. Each well of a 96 well ELISA plate was filled with $175 \mu \mathrm{L}$ of an exponentially growing culture $\left(10^{6}-10^{7} \mathrm{CFU} / \mathrm{mL}\right)$ and $20 \mu \mathrm{L}$ solution of each concentration of the test substance. The ELISA trays were incubated for 40 
minutes before $5 \mu \mathrm{L}$ of FDA $(2 \mathrm{mg} / \mathrm{mL})$ was added. Incubation was continued for a further 90 minutes and the resulting green colour from the hydrolysis of FDA was measured at $490 \mathrm{~nm}$ (reference to $630 \mathrm{~nm}$ ) and blank against control wells containing microbial cultures only.

Brine shrimps lethality assay. Test sample was dissolved in DMSO and varying concentrations of samples were prepared and each sample solution (100 $\mu \mathrm{L})$ was added into a well of a 96 microtitre plate containing $100 \mu \mathrm{L}$ of sea water and 10-12 Artemia salina shrimp larvae. After 24 hours, the number of dead larvae in each well was counted and the percentage mortality was calculated for the 3 replicates. $\mathrm{An}^{\mathrm{LC}_{50}}$ value (i.e., the concentration of cell extract which caused 50\% mortality) for each sample was determined using the Probit analysis method described by Finney. ${ }^{16}$

Isolation of compound from Nodularia sp. Supernatant of $N$. spumigena (25 Litres) were applied to a reversed phase flash chromatography system fitted with a C-18HS column $(7.5 \times 4.0 \mathrm{~cm}$, i.d. 35-70 $\mu \mathrm{m}$ particle size, $60^{\prime}$ pore size). A step gradient of 10 to $100 \%$ aqueous methanol in $20 \%$ increments (500 $\mathrm{mL}$ per step) was used to elute different toxins from the column and five fractions were collected. All fractions were dried under reduced pressure at $40^{\circ} \mathrm{C}$ and resuspended in $50 \mathrm{~mL}$ Milli-Q-Water and analyzed by HPLC. Column washing with $100 \%$ methanol fraction showed interesting peak other than toxins. This fraction was passed through a C-18-HS column $(15 \times 4.0 \mathrm{~cm}$, i.d. $35-70 \mu \mathrm{m}$ particle size, 60 A pore size). A step gradient of 10 to $100 \%$ aqueous methanol in $10 \%$ increments (500 mL per step) was used to elute toxins from the column. The $90 \%$ aqueous methanol fraction showed interesting peak on HPLC and was further purified by reversed phase C18 HPLC column using the same solvent system with RI detector to yield $76 \mathrm{mg}$ of compound $\mathbf{1}$ as pale yellow liquid (Figure 1).

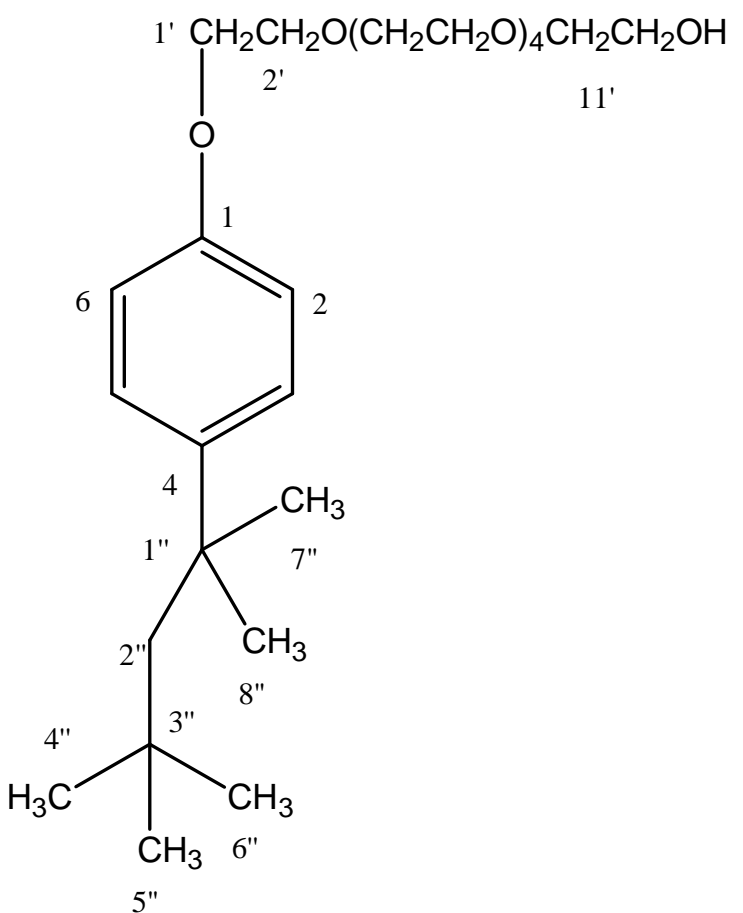

Figure 1. Structure of nodularinol.

\section{RESULTS AND DISCUSSION}

All fractions obtained from the supernatant of $M$. aeruginosa PCC 7804, M. aeruginosa Sciento and N. spumigena were analyzed by HPLC. The chromatograms of standard microcystin LR (retention time: $24.04 \mathrm{~min}$ ) and nodularin (retention time: 24.04 min) are presented in the Figure 2 and 3. It was found that microcystin LR was present in $25 \%, 50 \%$ and $75 \%$ aq. methanol fraction of $M$. aeruginosa PCC 7804 and $50 \%$ aq. methanol fraction of $M$. aeruginosa Sciento. The $50 \%$ aq. methanol fraction of $N$. spumigena contained nodularin. Comparing the chromatographs with standard microcystin LR and nodularin it is assumed that $25 \%, 50 \%$ and $75 \%$ aq. methanol fraction of $M$. aeruginosa PCC7804 contained approximately 22.6, 157 and $31.2 \mu \mathrm{g} / \mathrm{mL}$ toxins, respectively, while $50 \%$ aq. methanol fraction of $M$. aeruginosa Sciento and $50 \%$ aq. methanol fraction of $N$. spumigena contained 10 and 28.2 $\mu \mathrm{g} / \mathrm{mL}$ toxins. Other fractions were found to contain an average amount of toxins. 
Table 1. ${ }^{1} \mathrm{H}(\delta$ in ppm, proton count, multiplicity in $\mathrm{Hz}),{ }^{13} \mathrm{C}$ NMR $(\delta$ in ppm) and HMBC data of compound 1.

\begin{tabular}{|c|c|c|c|}
\hline Carbon & ${ }^{13} \mathrm{C}$ & ${ }^{1} \mathrm{H}$ & $\mathrm{HMBC}(\mathrm{C} \rightarrow \mathrm{H})$ \\
\hline 1 & 156.8 & - & $4.05,6.82,7.25$ \\
\hline 2,6 & 113.7 & $6.82(1 \mathrm{H}, \mathrm{d}, J=8.8)$ & $6.82,7.25$ \\
\hline 3,5 & 127.0 & $7.25(1 \mathrm{H}, \mathrm{d}, J=8.8)$ & 1.30 \\
\hline 4 & 142.1 & - & $1.30,1.70,6.82$ \\
\hline 1 ' & 67.3 & $4.05(2 \mathrm{H}, \mathrm{m})$ & 3.78 \\
\hline $2^{\prime}$ & 69.7 & $3.78(2 \mathrm{H}, \mathrm{m})$ & 4.05 \\
\hline $3^{\prime}$ & 70.2 & $3.58(2 \mathrm{H}, \mathrm{m})$ & \\
\hline $4^{\prime}$ & 70.3 & $3.58(2 \mathrm{H}, \mathrm{m})$ & 3.58 \\
\hline 5 , & 70.4 & $3.58(2 \mathrm{H}, \mathrm{m})$ & \\
\hline $6^{\prime}$ & 70.4 & $3.58(2 \mathrm{H}, \mathrm{m})$ & \\
\hline 7 ' & 70.4 & $3.58(2 \mathrm{H}, \mathrm{m})$ & \\
\hline 8 ' & 70.3 & $3.58(2 \mathrm{H}, \mathrm{m})$ & \\
\hline 9' & 70.4 & $3.58(2 \mathrm{H}, \mathrm{m})$ & \\
\hline 10 ' & 70.5 & $3.58(2 \mathrm{H}, \mathrm{m})$ & \\
\hline $11^{\prime}$ & 72.5 & $3.51(2 \mathrm{H}, \mathrm{m})$ & 3.61 \\
\hline $12^{\prime}$ & 61.0 & $3.61(2 \mathrm{H}, \mathrm{m})$ & 3.51 \\
\hline $1 "$ & 37.7 & - & $1.30,1.70,7.25$ \\
\hline $2 "$ & 56.9 & $1.70(2 \mathrm{H}, \mathrm{s})$ & $0.67,1.30$ \\
\hline $3 "$ & 32.0 & - & 0.67 \\
\hline $4 "$ & 31.1 & $0.67(3 \mathrm{H}, \mathrm{s})$ & \\
\hline 5 " & 31.1 & $0.67(3 \mathrm{H}, \mathrm{s})$ & \\
\hline 6 " & 31.1 & $0.67(3 \mathrm{H}, \mathrm{s})$ & \\
\hline 7, & 31.2 & $1.30(3 \mathrm{H}, \mathrm{s})$ & 1.70 \\
\hline $8^{\prime \prime}$ & 31.2 & $1.30(3 \mathrm{H}, \mathrm{s})$ & 1.70 \\
\hline
\end{tabular}

The ${ }^{1} \mathrm{H}$ NMR spectrum of compound 1 indicated the presence of a 1,4-disubstituted benzene ring system by the signals at $\delta 7.25(\mathrm{~d}, J=8.8 \mathrm{~Hz})$ and $6.68(\mathrm{~d}, J=8.8 \mathrm{~Hz}) \mathrm{ppm}$. The ${ }^{13} \mathrm{C}$ NMR spectra data of compound 1 revealed that it had 26 carbons and the DEPT spectra indicated the presence of thirteen oxygenated methylenes $(\delta 72.5,70.4,70.4,70.4$, $70.4,70.4,70.3,70.3,70.2,69.7,67.3,61.0,56.9)$, four methines $(\delta 125.8,125.8,113.7,113.7)$, four quaternary carbons $(\delta 156.8,142.1,37.7,31.9)$ and five methyls $(\delta 31.2,31.2,31.1,31.1,31.1)$. All protonated carbons were assigned by an HSQC experiment. The ${ }^{1} \mathrm{H}^{1}{ }^{1} \mathrm{H}$ COSY showed correlation between $7.26 \& 6.82 \mathrm{ppm}, 4.05 \& 3.78 \mathrm{ppm}$ and 3.51 \& $3.61 \mathrm{ppm}$. Long range HMBC correlations were observed between $\delta_{\mathrm{C}} 156.8$ to $\delta_{\mathrm{H}} 7.25 \& 6.82 ; \delta_{\mathrm{C}}$ 142.1 to $\delta_{\mathrm{H}} 6.82 ; \delta_{\mathrm{C}} 72.5$ to $\delta_{\mathrm{H}} 3.61 ; \delta_{\mathrm{C}} 37.7$ to $\delta_{\mathrm{H}}$ $1.30 \& 1.70 ; \delta_{\mathrm{C}} 56.9$ to $\delta_{\mathrm{H}} 1.30 \& 0.67$. The low resolution mass spectrum (LRMS) showed a molecular mass of $493.1[\mathrm{M}+\mathrm{Na}]^{+}$which suggested that compound $\mathbf{1}$ had the molecular formula $\mathrm{C}_{26} \mathrm{H}_{46} \mathrm{O}_{7}$. By combination of ${ }^{1} \mathrm{H}-{ }^{1} \mathrm{H}$ COSY, HSQC,
HMBC and mass spectral data the structure of the compound was confirmed and we named as nodularinol (Figure 1). Nodularinol is an unusual new metabolite from the extract of cyanobacteria and might be the result of contamination from the medium.

Minimum inhibitory concentration (MIC) of streptomycin by the FDA spectrophotometric method was $8 \mathrm{mg} / \mathrm{mL}$. This value was used as standard for determining the MICs of tested samples. As the FDA assay relies on a change in visible wavelength, coloured samples give abnormal results. The 25\% and $50 \%$ aq. methanol fraction of all the three toxin samples contained a lot of coloured materials which affected the value. The results of $25 \%$ and $50 \%$ aq. methanol fraction of $M$. aeruginosa 7820 were found that they had nearly the same absorbance at all concentrations and do not have a sharp decline in the absorbance. The $75 \%$ and $100 \%$ fraction of $M$. aeruginosa 7820, M. aeruginosa Sciento and $N$. spumigena were found to be 12.0, 12.5, 16.25, 16.75, $17.25,17.50 \mathrm{mg} / \mathrm{mL}$, respectively. Although this 

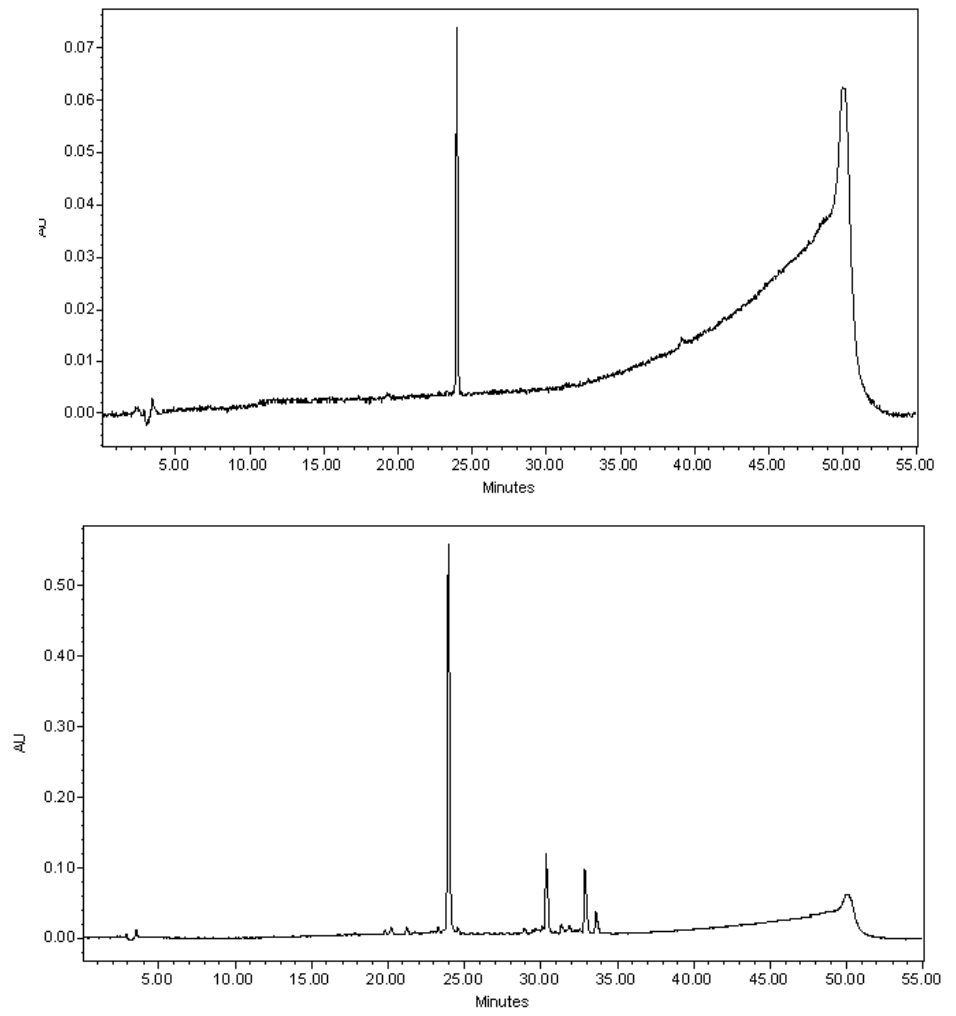

Figure 2. HPLC chromatogram of microcystin LR in standard solution (A) and extract (B).
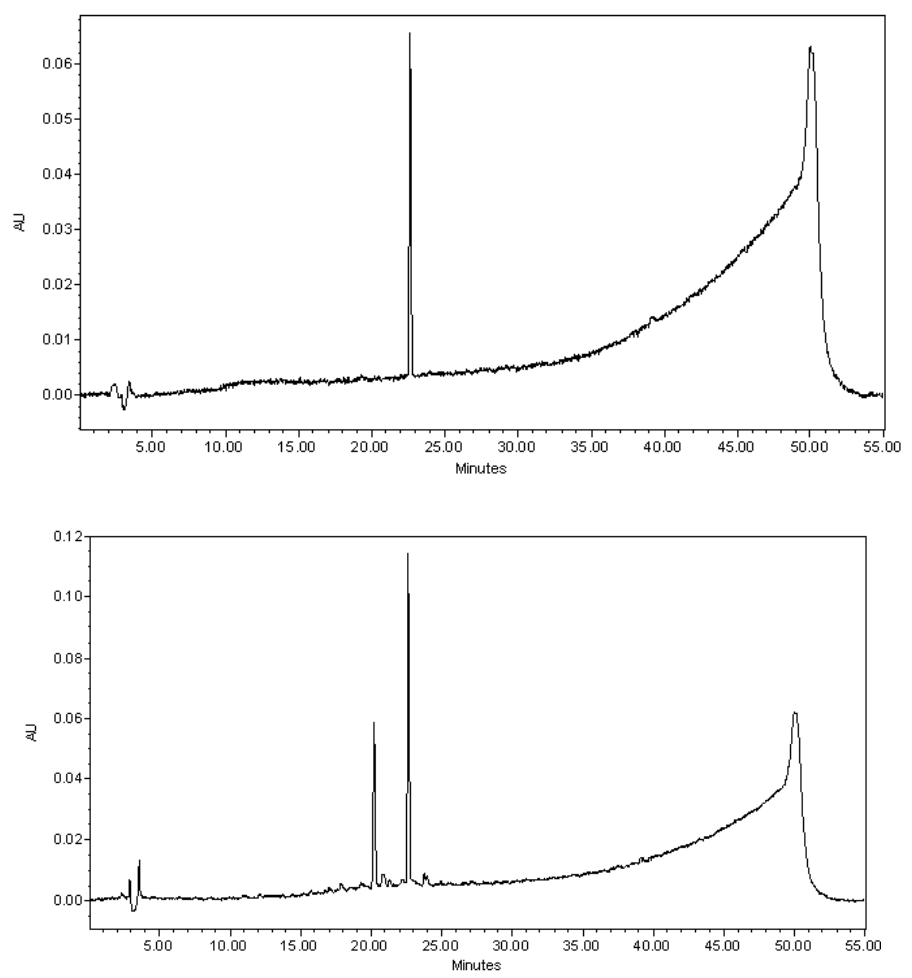

Figure 3. HPLC chromatogram of nodularin in standard solution (A) and extract (B). 
method is very rapid and convenient for determining the MIC of a large number of samples within 2 hours, it is sometimes difficult to use for toxin samples. Most of the cyanobacterial toxin samples contain colouring materials due to the presence of chlorophyll b which causes abnormal absorbance value. Therefore, it is better to remove the colouring materials from the toxin samples for determination of MIC by FDA method. Charcoal can be used to remove colour. Due to charcoal's adsorption activity, colouring materials can bind with it and the samples can be decolorized by filtration. Again, charcoal may absorb compound of interest too. So special care should taken during handling charcoal

The $\mathrm{LC}_{50}$ values of $25 \%, 50 \%$ and $75 \%$ aqueous $\mathrm{MeOH}$ fraction of $M$. aerugionosa had reasonable $\mathrm{LC}_{50}$ values with 32,36 and $78 \mu \mathrm{g} / \mathrm{mL}$, respectively. Other fractions had moderate activity with $\mathrm{LC}_{50}$ values in the range of $118-176 \mu \mathrm{g} / \mathrm{mL}$. The significant toxic activity of fractions of $M$. aerugionosa might be due to the presence of more toxins. The $\mathrm{LC}_{50}$ value of microcystin $\mathrm{LR}$ was found to be $3.2 \mu \mathrm{g} / \mathrm{mL}$.

\section{ACKNOWLEDGEMENTS}

The author thanks Professor Marcel Jaspars, Department of Chemistry, University of Aberdeen, UK and Professor Linda A Lawton for their supports and guidance to carry out the whole work in their laboratories and Ministry of Science and Technology, Government of the People's Republic of Bangladesh for awarding Bangabhandhu Fellowship.

\section{REFERENCES}

1. Priscu, J.C., Fritsen, C.H., Adams, E.E., Giovannoni, S.J., Paerl, H.W., McKay, C.P., Doran, P.T., Gordon, D.A., Lanoil, B.D. and Pinckney, J.L. 1998. Perennial Antarctic lake ice: An Oasis for life in a polar desert. Science. 280, 2095-2098.

2. Vincent, W.F. 2000. Cyanobacterial dominance in the polar regions. In: The Ecology of Cyanobacteria (Whitton, B.A. and Potts, M., Eds.), London: Kluwer Academic Publishers, pp. 321-340.
3. Wynn-Williams. 2000. Cyanobacteria in desserts-life at the time? In: The Ecology of Cyanobacteria (Whitton, B.A. and Potts, M., Eds.), London: Kluwer Academic Publishers, pp. 341-366.

4. Oren, A. 2000. Salts and brines. In: The Ecology of Cyanobacteria (Whitton, B.A. and Potts, M., Eds.), London: Kluwer Academic Publishers, pp. 281-306.

5. Castenholz, R.W. 1969. Thermophilic blue-green algae and the thermal environment. Bacteriol. Rev. 33, 476-505.

6. Jaspars, M and Lawton, A.L. 1998. Cyanobacteria-a noble source of pharmaceuticals. Curr. Opin. Drug Discovery Dev. 1, 77-84.

7. Konst, H., McKercher, P.D., Gorham, P.R., Robertson, A. and Howell, J. 1965. Symptoms and phathology produced by toxic Microcystis aeruginosa NRC-1 in laboratory and domestic animals. Can. J. Comp. Med. Vet. Sci. 29, 221-228.

8. Rinehart, K.L., Harada, K-I., Namikoshi, M., Chen, C. and Harvis, C.A., Munro, M.H.G., Blunt, J.W., Mulligan, P.E, Beasley, V.R., Dahlem, A.M. and Carmichael, W.W, 1988. Nodularin, microcystin and configuration of Adda. J.A. Chem. Soc. 110, 8557-8558.

9. Sivonen, K. and Jones, G. 1999. Cyanobacterial Toxins. In: Chorus I., and Bartram, J. (Eds.), London, pp. 41-111.

10. Francis, G. 1878. Poisonous Australian lake. Nature 18, 1112.

11. Chand, S., Lusunzi, I., Veal, D.A., Williams, L.R. and Karuso, P. 1994. Rapid screening of the antimicrobial activity of extracts and natural products. J. Antibiotics. 47, 1295-1303.

12. Wanandy, S., Brouwer, N., Liu, Q., Mahon, A., Cork, S., Karuso, P., Vemulpad, S. and Jamie, J. 2005. Optimization of the fluorescein diacetate antibacterial assay. J. Microbiol Method. 60, 21-30.

13. Meyer, B.N., Ferringni, N.R., Puam, J.E., Lacobsen, L.B., Nichols D.E. and McLaughlin, J.L. 1982. Brine shrimp: a convenient general bioassay for active constituents. Planta Med. 45, 31-32.

14. Stainer, R.Y., Kunisawa, R., Mandel, M. and Cohen-Bazire, G. 1971. Purification and properties of unicellular blue green algae (order Chroococcales). Bacteriol Rev. 35, 171-205.

15. Bauer, A. W., Kirby, M. M.W., Sherris, C. J. and Turck, M. 1966. Antibiotic susceptibility testing by a standardized single disk method. Am. J. Clin. Path. 45, 493-496.

16. Finney, D. J. 1971. Probit Analysis, $3^{\text {rd }}$ Ed., Cambridge University Press, Cambridge. 